\title{
SOCIAL SKILLS DEVELOPMENT OF ELEMENTARY SCHOOL STUDENTS IN RELATION TO THE EDUCATIONAL LEVEL OF THEIR PARENTS
}

Alma Malkić Aličković ${ }^{1}$

Faculty of Philosophy, University of Tuzla, Bosnia and Herzegovina

\author{
Original scientific paper
}

Received: 2019/1/8

Accepted: 2019/3/12

\begin{abstract}
Social skills are one of the fundamental factors that determine the quality of relationships that an individual realizes with people in his or her environment. In the interpersonal relationship, many human needs are realized, and the learning of the skills that enrich interpersonal relationships starts from the earliest days of the child's life. The paper presents the results of the research aimed at examining the social skills of elementary school pupils in relation to the educational level of their parents. The survey was carried out on the sample of elementary school students from the city of Tuzla ( $N$ =506). As the research tool, Inventory of Social Skills (Riggio and Throckmorton) and the Questionnaire of Socio-status Characteristics were used. The social skills of the respondents were analyzed separately in relation to the educational level of the mother and father, and the results obtained point to the conclusion that there is no statistically significant difference between the social skills of elementary school students in view of the educational level of their mothers, while the differences are present in relation to the educational level of the father, that is, elementary school pupils whose fathers are of lower educational level show a higher level of development of emotional control, social sensitivity and social manipulation.
\end{abstract}

Keywords: social skills, parenting, verbal social skills, non-verbal social skills.

\section{INTRODUCTION}

By nature, man is directed to other people and most needs and potential can be achieved through social interaction. However, the success of each individual in this context is determined by his social skills, which in the most significant sense imply success in establishing and maintaining positive interpersonal relationships.

Children who have developed social skills simply work outside the family environment in which they are mostly inclined. These children are successful in achieving contacts and establishing friendships with peers. Also, when they go to school, they are successfully affiliated in the classroom (Urdan \& Maehr, 1995, according to Mapiasse, 2007) and have a positive attitude towards the school (Denham, et al., 2003). In their research, Segrini Taylor (2007) found that the development of social skills is strongly linked to positive relationships with others, quality of life and optimism, while Spasenović (2009) found social adherence as a significant predictor of school success.

\footnotetext{
${ }^{1}$ Correspondence to:

Alma Malkić Aličković, Faculty of Philosophy, University of Tuzla, Bosnia and Herzegovina

Dr. Tihomila Markovića 1, 75000 Tuzla, Bosnia and Herzegovina

Phone:+387 63000470

E-mail:almamalki@yahoo.de
} 
Exploring the reasons why some scientists are unsuccessful at work, even though intelligence and non-education do not lag behind colleagues, Alan Frehman (according to Shapiro, 1997) pointed to the importance of social skills in this context, finding that individuals lack isolation and social skills isolate themselves and therefore their performance at work is weaker.

In the first years of the child's life, the learning of social skills is most strongly contributed by the family's conservative atmosphere, which is characterized by emotional warmth and respect for the child's needs from one hand, and the setting of demands and borders before the child, on the other. In this environment, they have the basic skills necessary for functioning in the game, and later with the expansion of the network of social relationships, which is accompanied and promoted by the child's cognitive development, the repertoire of social skills in his behavior is expanding.

Parental contribution to the development of social skills in children is realized directly in a way that social competence is demonstrated by its own example, and indirectly, which implies providing specific, explicit instructions on how a child should behave. Covey (1998) points out that providing modeling is the most important form of influence parents have on a child, because what they see in parents' behavior far more leaves a mark on children than a voice instruction.

Klarin (2002) conducted a survey on a sample of 263 children aged 10 to 14 in Zagreb, in order to examine the relationship between the quality of family interactions and child's peer relationships. The results that have been reported indicate that children with parental involvement, an open relationship, a relationship of trust and understanding, make that relationship with their best friend, and that the care and support that parents provide to the child stimulates the behavioral mechanisms that are desirable in relationship with a friend. Children who are accepted by parents have a positive image of themselves and are less rejected by their peers. When it comes to parental influence on the child in general, and so in the context of learning social skills, it is necessary to take into account the specificity of parenting of mother and father and treat them accordingly. In order to emphasize the importance of the father's educational role, which, unlike maternal much less explored and often reduced to foster care only, today it is increasingly tending to the other extreme, which is to identify the educational role of the father with the mother's. Bergmann (2007, p. 81) states that paternity is increasingly viewed "as an auxiliary service for the mother" or as "a complement to motherhood, but not as something in principle different". However, taking into account the differences in their biological predisposition, it should be emphasized that the father and mother since the first days of the child's life contribute to its development in various ways, and therefore, as Sigman (2011, p. 84) points out, "the unique and necessary contribution of men and women as a parent should be praised, not disputed. "The mothers are those who promote safety and help the child to develop empathy and relate their behavior emotionally to the influence on others, while the fathers examine the boundaries and from them children learn more about how to cope in society and associate their behavior with the consequences (Sigman, 2011). The mother plays the role of patron, and the child often seeks maternal support and protection, while preferring to play with the father (Klarin, 2006).

In the set of factors that determine successful parenting, there is also the educational level of parents. When it comes to research concerning the role of the educational level of parents in relation to the social skills and competences of their children, they are mainly oriented towards the educational role of the mother, and the results support the thesis that children of mothers with a higher level of education have a higher level of development of social skills. Thus, Sindik and Lukačić (2012), examining the social competences of pre-school children, in terms of gender, the educational level of the mother and the number of brothers and sisters, concluded that socially more competent children are the ones with mothers with higher education, while Brajša - Žganec (2003) found that children of pre-school age whose mothers have a higher level of education manifest less aggressive behavior in the kindergarten environment.

\section{METHODS}

The aim of the research is to examine the social skills of elementary school students, considering the educational level of their parents. In line with the aim, a research hypothesis was also set up, which assumes that there is a statistically significant difference between the results achieved by the elementary school pupils on the Inventory of Social Skills and in relation to the educational level of their parents. A sample of the research was made up of 506 students from six elementary schools from the city of Tuzla. The selection of schools where the research was conducted was made using the Spss quasi-random number generator. In the same way, the class collectives in which the survey was conducted, i.e., sample survey is random. Having in mind the gender of the respondents, the structure of the sample consisted of 225 girls and 281 boys. 
The age of the respondents ranges from 11 to 14 years, i.e., the sample included 110 students of the fifth, 129 students of the sixth, 122 students of the seventh and 145 students of the eighth grade.

To measure social skills, the Inventory of Social Skills ISS (Riggio and Throckmorton, 1986) was used, while for the purpose of obtaining data on the educational level of the parents of the respondents, the Questionnaire of socio-status characteristics was applied. The modified version of the Inventory of Social Skills, used for the purposes of this paper, consists of 28 items classified into seven subscales, namely two domains of the Inventory: emotional-non-verbal and social-verbal. The emotional-non-verbal domain of the Inventory consists of three subscales: Emotional expression, Emotional sensitivity and Emotional control, while the social-verbal domain of the Inventory is composed of four subscales: Social expression, Social sensitivity, Social control and Social manipulation. Each subscale consists of 4 particles represented in the form of a Likert type scale with response modes from 0 to $8(0=$ complete disagreement, $8=$ total agreement).

The subscale Emotional expression reflects the skill of expressing emotions in a non-verbal way. Subscale Emotional sensitivity is a measure of the skill of decoding non-verbal messages, while Subscale of Emo- tional control measures the ability to control their own emotions. Together, these three skills constitute an index of general emotional / non-verbal competence.

Subscales of the social-verbal domain of the Inventory reflect the verbal communication skills, whereby the Subscale of Social sensitivity is a measure of decoding and understanding of verbal communication, the Subscale of Social expression is a measure of veil expression and the ability to involve others in social interaction, while the Subscale of Social control refers to measuring the self-representing and playing skills role. Subscale Social manipulation is a measure of manipulation in communication with other people.

\section{RESULTS}

\section{Social skills of elementary school students with re- gard to the educational level of the mother}

Indicators that reflect the results of the respondents on the Inventory of Social Skills, with regard to the educational level of the mother, were analyzed individually for the Emotional-Non-verbal and Social-Verbal Area of the Inventory, and presented in the tables as follows.

Table 1. Descriptive indicators of the results of the respondents on the scales of the Emotional non-verbal area of the ISS in relation to the educational level of the mother

\begin{tabular}{lccccccc} 
& & $\mathbf{N}$ & $\mathbf{M}$ & SD & Std. Error & Min. & Max. \\
\hline Emotional & ES & 77 & 17.80 & 5.63 & .64 & .00 & 28.00 \\
& HSE & 247 & 17.19 & 5.52 & .35 & 5.00 & 32.00 \\
& AC & 82 & 17.55 & 6.66 & .73 & 6.00 & 32.00 \\
& UD & 100 & 17.44 & 6.17 & .61 & 3.00 & 31.00 \\
\hline Emotional & Total & 506 & 17.39 & 5.85 & .26 & .00 & 32.00 \\
\hline sensitivity & ES & 77 & 21.06 & 7.34 & .84 & 1.00 & 32.00 \\
& HSE & 247 & 21.43 & 6.34 & .40 & 3.00 & 32.00 \\
& AC & 82 & 20.72 & 6.15 & .68 & 8.00 & 32.00 \\
& UD & 100 & 19.75 & 7.71 & .77 & .00 & 32.00 \\
\hline Emotional control & Total & 506 & 20.93 & 6.77 & .30 & .00 & 32.00 \\
& ES & 77 & 19.48 & 6.99 & .79 & 2.00 & 32.00 \\
& HSE & 246 & 18.16 & 6.61 & .42 & 1.00 & 32.00 \\
& AC & 82 & 17.45 & 6.85 & .76 & .00 & 32.00 \\
& UD & 100 & 16.72 & 7.35 & .73 & .00 & 32.00 \\
& Total & 505 & 17.96 & 6.89 & .31 & .00 & 32.00 \\
\hline
\end{tabular}


For the purpose of checking the homogeneity of the and there are no statistically significant differences, subgroup variant, the Leven test procedure was ap- so Variance Analysis was applied to determine the plied, which indicates that the variances are uniform differences between groups.

Table 2. Variation analysis for the Emotional-non-verbal area of the Inventory, in relation to the variable "educational level of the mother"

\begin{tabular}{ccccccc}
\hline & & Sum of the square & df & Middle square & F & $p$ \\
\hline Emotional & Between the groups & 25.04 & 3 & 8.35 & .24 & .87 \\
expression & Within the group & 17289.69 & 502 & 34.44 & & \\
& Total & 17314.74 & 505 & & & \\
\hline Emotional & Between the groups & 205.81 & 3 & 68.60 & 1.50 & .21 \\
sensitivity & Within the group & 22928.48 & 502 & 45.67 & & \\
& Total & 23134.29 & 505 & & & \\
\hline Emotional & Between the groups & 363.10 & 3 & 121.03 & 2.57 & .05 \\
control & Within the group & 23585.18 & 501 & 47.07 & & \\
& Total & 23948.28 & 504 & & & \\
& &
\end{tabular}

In Table 2 it is evident that there is no statisti- Emotional-non-verbal Area of the Inventory, and in cally significant difference in the results achieved relation to the educational level of the mother $(p>$ by elementary school students in scales from the .05).

Table 3. Descriptive indicators of respondents' results on the scales of the Socio-verbal area of the Inventory, in relation to the educational level of the mother

\begin{tabular}{cccccccc}
\hline & & N & M & SD & Std. Error M & Min. & Max. \\
\hline Social expression & ES & 77 & 19.51 & 5.58 & .64 & 4.00 & 30.00 \\
& HSE & 247 & 19.31 & 5.87 & .37 & 0.00 & 32.00 \\
& AC & 82 & 18.99 & 5.41 & .60 & 8.00 & 32.00 \\
& UD & 100 & 18.87 & 5.87 & .59 & 6.00 & 31.00 \\
& Total & 506 & 19.20 & 5.74 & .25 & .00 & 32.00 \\
\hline Social sensitivity & ES & 77 & 22.57 & 6.22 & .71 & 7.00 & 32.00 \\
& HSE & 247 & 22.07 & 5.39 & .34 & 6.00 & 32.00 \\
& AC & 82 & 20.46 & 5.07 & .56 & 5.00 & 30.00 \\
& UD & 100 & 21.16 & 6.14 & .61 & 5.00 & 32.00 \\
& Total & 506 & 21.70 & 5.65 & .25 & 5.00 & 32.00 \\
\hline Social control & ES & 77 & 19.26 & 5.88 & .67 & 1.00 & 32.00 \\
& HSE & 247 & 18.60 & 5.47 & .35 & 3.00 & 32.00 \\
& AC & 82 & 18.83 & 5.44 & .60 & 3.00 & 30.00 \\
& UD & 100 & 17.48 & 6.47 & .65 & 3.00 & 32.00 \\
Social & Total & 506 & 18.52 & 5.75 & .25 & 1.00 & 32.00 \\
\hline manipulation & ES & 77 & 18.61 & 5.56 & .63 & 6.00 & 29.00 \\
& HSE & 247 & 18.60 & 5.22 & .33 & 3.00 & 32.00 \\
& AC & 82 & 19.07 & 5.89 & .65 & 3.00 & 32.00 \\
& UD & 100 & 20.16 & 5.94 & .59 & 3.00 & 32.00 \\
& Total & 506 & 18.99 & 5.54 & .25 & 3.00 & 32.00 \\
\hline
\end{tabular}

Using the Leven test, a variance homogeneity test was performed, which found that the variance was uniform and that there were no statistically significant differences, which allowed the application of the Variance Analysis to determine the difference between the results obtained by respondents on the Scales of the Socio-verbal area of the Inventory (Table 4). 
Table 4. Variance analysis for the subscales of the Social-verbal area of the Inventory in relation to the variable „educational level of the mother"

\begin{tabular}{|c|c|c|c|c|c|c|}
\hline & & Sum of the square & df & Middle square & $\mathbf{F}$ & $p$ \\
\hline \multirow[t]{3}{*}{ Social expression } & Between the groups & 25.12 & 3 & 8.37 & .25 & .86 \\
\hline & Within the group & 16636.91 & 502 & 33.14 & & \\
\hline & Total & 16662.03 & 505 & & & \\
\hline \multirow[t]{3}{*}{ Social sensitivity } & Between the groups & 246.60 & 3 & 82.20 & 2.59 & .05 \\
\hline & Within the group & 15926.51 & 502 & 31.73 & & \\
\hline & Total & 16173.12 & 505 & & & \\
\hline \multirow[t]{3}{*}{ Social control } & Between the groups & 159.85 & 3 & 53.28 & 1.61 & .18 \\
\hline & Within the group & 16540.49 & 502 & 32.95 & & \\
\hline & Total & 16700.34 & 505 & & & \\
\hline \multirow[t]{3}{*}{ Social manipulation } & Between the groups & 185.50 & 3 & 61.83 & 2.02 & .11 \\
\hline & Within the group & 15344.43 & 502 & 30.56 & & \\
\hline & Total & 15529.93 & 505 & & & \\
\hline
\end{tabular}

By looking at the presented statistical indicators it is evident that there is no statistically significant difference between the results achieved on the scales from the Social-Verbal area by elementary school students whose mothers have different educational levels $(\mathrm{p}>.05)$.

\section{Social skills of elementary school students in relation to the educational level of the father}

The statistical procedure applied to the analysis of indicators that reflect the results of the respondents on the Inventory of Social Skills, given the educational level of the mother, was also applied in the analysis of these results of the respondents relative to the educational level of the father (Table 5).

Table 5. Descriptive indicators of respondents' results on the Inventory of Social Skills in relation to the educational level of the father

\begin{tabular}{cccccccc}
\hline & & & & & & & \\
& & $\mathbf{N}$ & $\mathbf{M}$ & SD & Std. Error M & Min. & Max. \\
\hline Emotional expression & ES & 41 & 17.93 & 5.63 & 0.88 & 4.00 & 32.00 \\
& HSE & 264 & 17.33 & 5.80 & 0.36 & 0.00 & 30.00 \\
& AC & 87 & 17.39 & 6.72 & 0.72 & 3.00 & 32.00 \\
& UD & 114 & 17.34 & 5.40 & 0.51 & 3.00 & 29.00 \\
& Total & 506 & 17.39 & 5.85 & 0.26 & 0.00 & 32.00 \\
\hline Emotional sensitivity & ES & 41 & 22.46 & 6.46 & 1.00 & 8.00 & 32.00 \\
& HSE & 264 & 21.42 & 6.61 & 0.41 & 1.00 & 32.00 \\
& AC & 87 & 19.96 & 6.60 & 0.71 & 8.00 & 32.00 \\
& UD & 114 & 19.97 & 7.20 & 0.67 & 0.00 & 32.00 \\
& Total & 506 & 20.93 & 6.77 & 0.30 & 0.00 & 32.00 \\
\hline Emotional control & ES & 41 & 20.07 & 6.29 & 0.98 & 6.00 & 32.00 \\
& HSE & 263 & 18.30 & 6.66 & 0.41 & 1.00 & 32.00 \\
& AC & 87 & 17.57 & 7.35 & 0.78 & 1.00 & 32.00 \\
& UD & 114 & 16.72 & 7.10 & 0.66 & 0.00 & 32.00 \\
& Total & 505 & 17.96 & 6.89 & 0.30 & 0.00 & 32.00 \\
\hline Social expression & ES & 41 & 19.36 & 5.97 & 0.93 & 4.00 & 30.00 \\
& HSE & 264 & 19.55 & 5.88 & 0.36 & 0.00 & 32.00 \\
& AC & 87 & 18.65 & 5.29 & 0.56 & 6.00 & 32.00 \\
& UD & 114 & 18.76 & 5.67 & 0.53 & 7.00 & 31.00 \\
& Total & 506 & 19.20 & 5.74 & 0.25 & 0.00 & 32.00 \\
\hline Social sensitivity & ES & 41 & 24.43 & 5.03 & 0.79 & 12.00 & 32.00 \\
& HSE & 264 & 21.83 & 5.60 & 0.34 & 6.00 & 32.00 \\
& AC & 87 & 20.42 & 5.49 & 0.59 & 5.00 & 31.00 \\
& UD & 114 & 21.41 & 5.83 & 0.55 & 5.00 & 32.00 \\
& Total & 506 & 21.70 & 5.66 & 0.25 & 5.00 & 32.00 \\
\hline
\end{tabular}




\begin{tabular}{cccccccc}
\hline & & & & & & & \\
& & $\mathbf{N}$ & $\mathbf{M}$ & SD & Std. Error M & Min. & Max. \\
\hline Social control & ES & 41 & 19.56 & 5.54 & 0.86 & 5.00 & 28.00 \\
& HSE & 264 & 18.94 & 5.90 & 0.36 & 1.00 & 32.00 \\
& AC & 87 & 18.16 & 5.05 & 0.54 & 3.00 & 31.00 \\
& UD & 114 & 17.43 & 5.85 & 0.55 & 3.00 & 32.00 \\
& Total & 506 & 18.52 & 5.75 & 0.25 & 1.00 & 32.00 \\
\hline Social manipulation & ES & 41 & 19.95 & 5.43 & 0.85 & 6.00 & 32.00 \\
& HSE & 264 & 18.32 & 5.35 & 0.33 & 3.00 & 32.00 \\
& AC & 87 & 19.61 & 5.90 & 0.63 & 3.00 & 32.00 \\
& UD & 114 & 19.72 & 5.62 & 0.53 & 3.00 & 32.00 \\
& Total & 506 & 18.98 & 5.54 & 0.25 & 3.00 & 32.00 \\
\hline
\end{tabular}

In order to verify the homogeneity of the subgroup variance, the method of the Leven test, whose results point to the uniformity of the variance, was used, and in order to verify the difference between the results obtained by respondents on the Inventory of Social Skills and in relation to the Educational level of the father, the Variance analysis was applied (Table 6).

Table 6. Single-factor analysis of variance for subscales of the Inventory of social skills in relation to the educational level of the father

\begin{tabular}{|c|c|c|c|c|c|c|}
\hline & & $\begin{array}{l}\text { Sum of the } \\
\text { square }\end{array}$ & df & $\begin{array}{l}\text { Middle } \\
\text { square }\end{array}$ & $\mathbf{F}$ & $\mathbf{p}$ \\
\hline \multirow[t]{3}{*}{ Emotional expression } & Between the groups & 12.92 & 3 & 4.30 & 0.12 & .94 \\
\hline & Within the group & 17301.82 & 502 & 34.47 & & \\
\hline & Total & 17314.74 & 505 & & & \\
\hline \multirow[t]{3}{*}{ Emotional sensitivity } & Between the groups & 344.11 & 3 & 114.70 & 2.52 & .05 \\
\hline & Within the group & 22790.18 & 502 & 45.40 & & \\
\hline & Total & 23134.29 & 505 & & & \\
\hline \multirow[t]{3}{*}{ Emotional control } & Between the groups & 401.95 & 3 & 133.98 & 2.85 & .03 \\
\hline & Within the group & 23546.33 & 501 & 46.99 & & \\
\hline & Total & 23948.28 & 504 & & & \\
\hline \multirow[t]{3}{*}{ Social expression } & Between the groups & 80.90 & 3 & 26.97 & .82 & .48 \\
\hline & Within the group & 16581.13 & 502 & 33.03 & & \\
\hline & Total & 16662.03 & 505 & & & \\
\hline \multirow[t]{3}{*}{ Social sensitivity } & Between the groups & 462.81 & 3 & 154.27 & 4.93 & .00 \\
\hline & Within the group & 15710.31 & 502 & 31.29 & & \\
\hline & Total & 16173.12 & 505 & & & \\
\hline \multirow[t]{3}{*}{ Social control } & Between the groups & 238.41 & 3 & 79.47 & 2.42 & .06 \\
\hline & Within the group & 16461.93 & 502 & 32.79 & & \\
\hline & Total & 16700.34 & 505 & & & \\
\hline \multirow[t]{3}{*}{ Social manipulation } & Between the groups & 251.02 & 3 & 83.67 & 2.75 & .04 \\
\hline & Within the group & 15278.90 & 502 & 30.44 & & \\
\hline & Total & 15529.93 & 505 & & & \\
\hline
\end{tabular}

According to the results presented in Table 6, there is a statistically significant difference on the Scale of Emotional Control and the Scale of Social Manipulation $(\mathrm{p}<.05)$, as well as the Scale of Social Sensitivity
$(\mathrm{F}=4.93, \mathrm{p}<.01)$. The direction of these differences was determined by applying the Post Hoc Comparison procedure (Table 7). 
Table 7. Significance of differences between the results of the respondents on the scales Emotional Control, Social Sensitivity and Social Manipulation, and in relation to the educational level of the father

\begin{tabular}{|c|c|c|c|c|c|}
\hline & $\begin{array}{c}\text { (I) The } \\
\text { educational } \\
\text { level of father }\end{array}$ & $\begin{array}{c}\text { (J) The } \\
\text { educational level } \\
\text { of father }\end{array}$ & $\begin{array}{l}\text { The difference } \\
\text { between M (I-J) }\end{array}$ & Std. Error & $p$ \\
\hline \multirow[t]{6}{*}{ Emotional control } & & HSE & 1.77 & 1.15 & .12 \\
\hline & ES & $\mathrm{AC}$ & 2.50 & 1.30 & .05 \\
\hline & & UD & 3.35 & 1.25 & .00 \\
\hline & HSE & $\mathrm{AC}$ & .72 & .85 & .39 \\
\hline & & UD & 1.58 & .77 & .04 \\
\hline & $\mathrm{AC}$ & UD & .85 & .97 & .38 \\
\hline \multirow[t]{6}{*}{ Social sensitivity } & & HSE & 2.61 & .94 & .00 \\
\hline & ES & $\mathrm{AC}$ & 4.01 & 1.05 & .00 \\
\hline & & UD & 3.02 & 1.01 & .00 \\
\hline & HSE & $\mathrm{AC}$ & 1.40 & .69 & .04 \\
\hline & & UD & .42 & .63 & .50 \\
\hline & $\mathrm{AC}$ & UD & -.98 & .80 & .22 \\
\hline \multirow[t]{6}{*}{ Social manipulation } & & HSE & 1.63 & .92 & .08 \\
\hline & ES & $\mathrm{AC}$ & .34 & 1.04 & .74 \\
\hline & & UD & .23 & 1.00 & .82 \\
\hline & HSE & $\mathrm{AC}$ & -1.29 & .68 & .06 \\
\hline & & UD & -1.40 & .62 & .02 \\
\hline & $\mathrm{AC}$ & UD & -.11 & .78 & .89 \\
\hline
\end{tabular}

According to the data from Table 7, statistically significant difference was observed between the results achieved by children whose fathers have completed only elementary school, compared to those whose fathers have a university degree $(\mathrm{p}<.01)$. At the same time, pupils whose fathers have only elementary education show higher results. This is also the case with the results of the Social Sensitivity Scale, whereby the results of children whose fathers have elementary school completion are statistically significantly different in relation to children whose fathers have high school, academy and university qualifications ( $\mathrm{p}<$ $.01)$. The results of children whose fathers have completed high school education are statistically significantly different on the Scale of Emotional Control (p $<.05)$ and the Scale of Social Manipulation $(p<0.05)$ compared to the results of pupils whose fathers have academy qualifications, while the results of these students on the Scale of Social sensitivity significantly differ in relation to the results of pupils whose fathers have academy education $(\mathrm{p}<.05)$.

\section{DISCUSSION}

In the process of learning social skills in children, the roles of parents are of primary importance. Intense social changes, which are inherent in the time we live in, and which reflect on the family's educational function, increasingly complicate the role of parents, and it is necessary to empower parents' pedagogical competences.

In order to examine how the educational level of parents reflects on the process of learning and development of social skills in children, we have focused our attention on examining differences in the development of social skills of elementary school pupils, bearing in mind the educational level of their parents. Obtaining an insight into such indicators is one of the fundamental guidelines for understanding the phenomena of learning social skills in a family context, primarily having regard to the educational level of parents in this regard, as well as for identifying parents whose pedagogical perspective needs to be empowered to contribute and stimulate the development of socio-emotional skills of their children. Also, an understanding of social skills learning in different family settings, which is, inter alia, conditioned by the level of parent education is one of the indicators with which the pupils, having in mind the family educational environment from which they come, need additional educational work at school, in order to improve their socio-emotional development. 
The results we have come to suggest that there is no statistically significant difference in the development of social skills in elementary school children, when the variables of the mother's educational level are taken into account. As a basis for explaining this result, some findings can be found (Brown \& Sar, 1993; Kurdek \& Fine, 1994; Windle, 1992; Deković \& RabotegŠarić, 1997) that indicate that adolescents with close emotional ties with parents exhibit a higher level of social competence, self-esteem and responsibility, where they primarily satisfy the emotional, inner needs of the mother (Petrović \& Mihić, 2009). It is well known that mothers unconditionally provide love and support to their children and, thanks to the inherent natural feeling of upbringing, form a strong emotional connection with them and thus a space for greater influence, and probably contribute to the socio-emotional development of their children, while the educational level of the mothers, in this context, is not of primary importance. However, if we consider school as a place of "living and gaining experience", a higher educational level of mothers should imply a higher level of pedagogical culture, that is, to contribute to the improvement of their educational role in general, and also to that part of the greater possibility influences on the development of their children's social skills. Naturally, parenting is also to be seen from the perspective of the wider social context, which is shaped by a multitude of influences, and in that respect it is necessary to consider the time factor that mothers of higher education, especially those employed, spend with their children and dedication to joint activities is a "space" for learning social skills.

Contrary to our results, the researches mentioned earlier in this paper (Brajša-Žganec, 2003 and Sindik \& Lulačić, 2012) point to a different contribution of the mothers' educational level to the development of their children's social competences, i.e. pre-school children whose mothers have a higher educational level show a higher level of social competences. The reason for these differences between these and the results of our research can be related to the age of respondents, given that the network of social relationships with age is widening, so adolescents, besides parenting, are exposed to intertwined influence of teachers, peers, media while children of preschool age are exposed to a small number of influences, and dominant is parenting, which is more clearly reflected in the field of social skills and competences. Also, a preschool period in which a child is unable to meet a number of elementary needs independently implies greater involvement of parents in the child's daily activities and caring for them.

The results we have come to include the social skills of elementary school pupils with regard to the educational level of the father point to the existence of statistically significant differences in the results of the respondents on certain subscales of the Inventory, with the difference in direction being such that pupils whose fathers are of the lower educational level show significantly better results in the Scale of Emotional Control, Social Sensitivity and Social Manipulation, compared to the children whose fathers have higher education. Examining the relationship between interpersonal values and social status, Majstorović (1998) has come up with similar results, i.e. lower status parents present an environment conducive to the development of the child's orientation towards the group, while better living conditions and higher family status stimulate the development of personal independence. This phenomenon is interpreted in a way that children whose parents are of lower social status are more prone to investing in warmth, understanding, and helping the group to get the same in return. Since it is not rare in our society to treat lower education families as inferior, it is possible for these reasons that pupils whose fathers are of the lower educational level show more developed skills such as emotional control, social sensitivity and social manipulation, compared to children whose fathers have higher educational qualifications. In the literature, while emphasizing the educational role of the father, in addition to education, the emphasis is placed on involvement in children's activities. According to the results of the research Wherry (2003, according to Sremic \& Rijavac, 2010) aimed at examining the influence of parental involvement on students' school success, students whose parents participate in their activities more easily overcome their obligations, have better developed social skills, prefer to attend classes and are well adapted to the school environment. Stevenson and Baker (1987, according to Sremic \& Rijovic, 2010) noted the positive correlation between parent involvement in child activities. All of this points to a possible explanation of our results and in a way that more educated fathers are oriented to their own activities and obligations, and therefore are less involved in everyday activities of children and spend little time with them, unlike fathers who have lower educational status, who possibly through their commitment, closeness and involvement in everyday child activities contribute to their socio-emotional development. 


\section{CONCLUSIONS}

Social skills are one of the fundamental factors for the successful functioning of an individual in different social contexts, and in the process of their learning the role of parents is of primary importance. The influence on the development of social skills in children is realized directly and indirectly by the parents, where this influence is determined by numerous factors, such as: development of the social skills of the parents themselves, involvement of parents in children's activities, quality of interaction between parents and child, socio-economic status, etc.

In order to study the social skills of elementary school pupils and in relation to the educational level of their parents, in this paper we have come to the conclusion that there is no statistically significant difference between the social skills of elementary school students, given the educational level of the mother, while the social skills of elementary school students statistically differ significantly in relation to the educational level of the father, in the way that elementary school students, whose fathers are of lower educational level, show greater development of emotional control, social sensitivity and social manipulation.

Such results indicate the need to strengthen the pedagogical culture of the parents, regardlessof their educational level.

\section{REFERENCES}

Adler, E. (2013). Socijalne veštine - kako optimalno biti sa sobom i drugima u današnjem svetu. Novi Sad: Psihopolis.

Alić, A. (2012). Struktura i dinamika obiteljske kulture. Sarajevo: Dobra knjiga, Centar za napredne studije.

Alić, A. (2018). Kulturalni modeli odgajanje-uvod u antropologiju porodice. Sarajevo: Perfecta.

Babić Čikeš, A., \& Buško, V. (2015). Emocionalna inteligencija u ranoj adolescenciji: korelati sposobnosti upravljanja emocijama i predikcija školskog uspjeha. Društvena istraživanja, 1, 21-45.

Barušić, J. (2007). Samopredstavljanje: taktike i stilovi. Jastrebarsko: Naklada Slap.

Bergmann, W. (2007). Umijeće roditeljske ljubavi. Jastrebarsko: Naklada Slap.

Brajša-Žganec, A. (2003). Dijete $i$ obitelj: emocionalni i socijalni razvoj. Zagreb: Naklada Slap.

Covey, R. S. (1998). Sedam navika uspješnih obitelji. Zagreb: Mozaik knjiga.

Čudina - Obradović, M., \& Obradović, J. (2006). Psihologija braka i obitelji.Zagreb: Golden marketing-Tehnička knjiga.

Deković, M., \& Raboteg-Šarić, Z. (1997). Roditeljski odgojni postupci i odnosi adolescenata sa vršnjacima. Društvena istraživanja, 4-5, 427-445.
Denham, S. A., Blair, K. A., DeMulder, E., Levitas, I., Sawyer K., Major, S., \& Queenan P. (2003). Preschool Emotional Competence: Pathway to Social Competence?. Child Development, 74 (1), 238-256.

Klarin, M. (2002). Osjećaj usamljenosti i socijalno ponašanje djece školske dobi u kontekstu socijalne interakcije. Ljetopis studijskog centra socijalnog rada, 9/2, 249-257.

Klarin, M. (2006). Razvoj djece u socijalnom kontekstu. Jastrebarsko: Naklada Slap.

Ljubetić, M. (2014). Od suradnje do partnestva obitelji, odgojno-obrazovne ustanove i zajednice. Zagreb: ELEMENT.

Malkić-Aličković, A. (2017). Ispitivanje socijalnih vještina učenika osnovnoškolske dobi u odnosu na dob i spol. Školski vjesnik, 66 (3), 379-400.

Majsotović, N. (1998). Interpersonalne vrijednosti i socijalni status, Psihologija, 1-2, 67-78.

Mapiase, S. (2007). Infuence of the democratic climate of classrooms on student civic learning in North Sulawesi, Indonesia. International Education Journal, 8 (2), 393-407.

Petrović, J., \& Mihić, I. (2009). Polne razlike u sposobnosti prepoznavanja emocija na osnovu facijalnih ekspresija muškog i ženskog modela (u perodu rane adolescencije). Godišnjak Filozofskog fakulteta u Novom Sadu, Knjiga XXXIV, 15-26.

Riggio, R. E., Tucker, J., \& Coffaro, D. (1989). Social Skills and Empathy. Personality and Individual Differences, 10 (1), 93-99.

Riggio, R. E., Throckmorton, B., \& DePaola, S. (1990). Social Skills and Self-Esteem. Personality and Individual Differences, 11 (8), 799-804.

Riggio, R. E. \& Carney, D. C. (2003). Manual for the Sociall Skills Inventory. Reedwood City, CA: Mind Garden.

Ruegg, E. (2003). Social competence, transition plans and children with learning disabilities. Essays in Education, 7.

Segrin, C., Taylor, M. (2007). Positive interpersonal relationship mediate the association between social skills and psychological well-being. Personality andIndividual Differences, 43,637-646.

Shapiro, L. E. (1997). Kako razviti emocionalnu inteligenciju djeteta. Zagreb: Mozaik knjiga.

Sigman, A. (2011). Razmažena generacija - kako uništavamo budućnost naše djece. Novi Sad: Psihopolis.

Sindik, J., \& Lukačić, L. (2012). Razvijanje socijalne kompetencije kod djece predškolske dobi-primjena skale procjene, Naša škola, 59, 29-50.

Spasenović, V. (2009). Kvalitet socijalnih odnosa i školsko postignuće učenika različitog uzrasta. Zbornik instituta za pedagoška istraživanja, 2, 331-348.

Sremić, I., \& Rijavec, M. (2010). Povezanost percepcije majčinog i očevog roditeljsko ponašanja i školskog uspjeha kod učenika osnovne škole, Odgojne znanosti, 12 (2),347-360.

Uzelac, M., Bognar, L., \& Bagić, A. (1994). Budimo prijatelji. Zagreb: Centar za kulturu mira i nenasilja.

Warnes, E. D., Sheridan, S. M., Geske, J., \& Warnes, W. A. (2005). A Contextual Approach to the Assessment of Social Skills: Identifyng Meaningful Behaviors for Social Competence. Psychology in the School, 42(2), 173-187. 